\title{
Evaluation of the Humphrey A.D.E. breathing system
}

A new breathing circuit (the Humphrey A.D.E., double lever model) was evaluated in adults to determine (1) the fresh gas flow ( $F G F$ ) needed to achieve normocapnia during conirolled ventilation and to just induce rebreathing during spontaneous ventilation, (2) end-expired $\mathrm{CO}_{2}\left(\mathrm{PECO}_{2}\right)$ at those $\mathrm{FGF}$ values, (3) the standard deviation of $F G F$ requirements for controlled and spontaneous breathing (reliability of recommended FGF settings) and (4) the magnitude of change in $\mathrm{P} \in \mathrm{CO}_{2}$ produced by varying $F G F$ from the recommended values (sensitivity of the system). The FGFs that provided normocapnia with controlled ventilation and just induced rebreathing with spontaneous ventilation were $67 \pm 10$ and $52 \pm 7 \mathrm{ml} \cdot \mathrm{kg}^{-1} \cdot \mathrm{min}^{-1}$ (mean $\pm S D$ ), respectively. $\mathrm{PECO}$ values were $36.0 \pm 0.3$ and $41.6 \pm 3.9$ munH $g$ respectively. During controlled ventilation low reliability was offset by low sensitivity so that $P E \mathrm{CO}_{2}$ changed litle when $F G F$ was raised or lowered from reconmended values 10.2 $\left.\mathrm{mmHg} / \mathrm{ml} \cdot \mathrm{kg}^{-1} \cdot \mathrm{min}^{-1}\right)$. In contrast, during spontaneous wertilation low reliobiliny was additive with high sensitivity when using FGFs lower than the mean value that just induced rebreathing. A threshold was reciched where lowering $F G F$ from recommended values caused large changes in $\mathrm{PECO}_{2}(1$. $\mathrm{mmHg} / \mathrm{ml}^{\circ} \mathrm{kg}^{-1} \cdot \mathrm{min}^{-1}$ ). It is concluded that the FGF recam. mended by Humphrey for controlled ventilation is satisfactory. However, the FGF recommended by Humphrey for spontaneous ventilation may result in hypercapnia in some patients. This can be prevented either by using a higher FGF of $66 \mathrm{ml} \cdot \mathrm{kg}^{-1}$. min $^{-1}$ routinely in all patients or by using lower flows with $\mathrm{CO}_{2}$ monitoring.

\section{Key words}

EQUIPMENT: ANAESTHETIC BREATHING SYSTEMS: HUIIphrey A.D.E.; VENTILATION: controlled, spontaneous.

From the Department of Anesthesiology, University of Washington School of Medicine, Seattle, Washington.

Address correspondence to: Dr. Alan Artru, Department of Anesthesiology, RN-10, University of Washington School of Medicine, Seattle, WA 98195.
A new breathing circuit, the Humphrey A.D.E system,* has been proposed as a low flow, universal anaesthetic breathing system. ${ }^{1,2}$ Results of clinical trials by Humphrey $e t$ al..$^{1-4}$ and others ${ }^{5-6}$ provide some support for this proposal. However, several important ventilatory characteristics of the system have not been examined.

With the circuit set for controlled ventilation, Humphrey et al. reported that a fresh gas flow (FGF) of $70 \mathrm{ml} \cdot \mathrm{kg}^{-1} \cdot \mathrm{min}^{-1}$ provided normocapnia in adults when a ventilatory volume of $140 \mathrm{ml} \cdot \mathrm{kg}^{-1} \cdot \mathrm{min}^{-1}$ was used. ${ }^{2.3}$ However, the FGF requirement for controlled ventilation reported by Humphrey et al..$^{2,3}$ has been independently verified in only one preliminary study of five patients ${ }^{5}$ Further, no data have been reported on the reliability of recommended FGF settings (the variability of the FGF required to produce normocapnia) or the sensitivity of the system (the magnitude of the change in end-expired $\mathrm{CO}_{2}\left[\mathrm{PECO} \mathrm{CO}_{2}\right.$ produced by varying the FGF from the recommended value) for controlled ventilation.

With the circuit set for spontaneous ventilation, FGFs ranging from $45.6 \pm 14.9$ (mean $\pm S D$ ) to $56 \mathrm{ml}$. $\mathrm{kg}^{-1} \cdot \mathrm{min}^{-1}$ were reported to just induce rebreathing (minimum inspired $\mathrm{CO}_{2}$ rose from zero to $\mathrm{l}-2 \mathrm{mmHg}$ ) in anaesthetized adults. ${ }^{1,3,5,6}$ However, the $\mathrm{PeCO}_{2}$ at the FGF that just induced rebreathing was reported only in one preliminary study of five patients. ${ }^{5}$ The reliability of FGF settings was reported in two studies, ${ }^{1,6}$ but no data have been reported on the sensitivity of the system for spontaneous ventilation.

The present study was designed to determine (1) the FGF needed to achieve normocapnia during controlled ventilation and to just induce rebreathing (minimum inspired $\mathrm{CO}_{2}>2 \mathrm{mmHg}$ ) during spontaneous ventilation, (2) $\mathrm{P} \in \mathrm{CO}_{2}$ at those FGF values, (3) the standard deviation of FGF requirements for controlled and spontaneous breathing (reliability of recommended FGF settings) and (4) the magnitude of change in $\mathrm{PECO}_{2}$ produced by varying the FGF from recommended values (sensitivity of the system). Independent verification of FGF requirements is important because it confirms that the FGF recommendations proposed by Humphrey et al ${ }^{1-4}$ were derived from a representative sample population. The

*Dentsply Canada, Downsuiew, Ontario. 
reliability of recommended FGF settings is of interest because if the variability of FGF requirements is large, routine use of a mean value for FGF will result in a large proportion of patients being hypo- or hypercapnic. The sensitivity of the system is of interest because if large changes in $\mathrm{PECO}_{2}$ accompany an alternation of FGF, routine use of a mean value for FGF again will result in a large proportion of patients being hypo- or hypercapnic.

\section{Methods}

This study was approved by the Human Subjects Committee of the University of Washington, Seattle. Thirty-three adult patients undergoing elective, non-thoracic surgery and of ASA physical status I or II participated in the study. Patients received either no premedication or diazepam $10 \mathrm{mg}$ PO 90 min prior to induction of anaesthesia. Anaesthesia was induced with thiopentone $3-4 \mathrm{mg} \cdot \mathrm{kg}^{-1}$ IV, the trachea was intubated using succinylcholine $1.5 \mathrm{mg} \cdot \mathrm{kg}^{-1}$ IV to enhance muscle relaxation, and anaes. thesia was maintained with isoflurane ( 1.5 per cent, inspired) and nitrous oxide (60 per cent, inspired) in oxygen. Narcotics were not administered. Pancuronium $\geq 0.1 \mathrm{mg} \cdot \mathrm{kg}^{-1}$ IV was given to maintain muscle relaxation with no visible muscle twitch in response to percutaneous stimulation of the ulnar nerve. During this time ventilation was controlled using the double lever, noncoaxial version of the Humphrey A.D.E. system. A tidal volume of $12-15 \mathrm{ml} \cdot \mathrm{kg}^{-1}$ and a ventilator rate of $9-12$ breaths $\cdot \mathrm{min}^{-1}$ were used to achieve the recommended ventilatory wolume of $135-140 \mathrm{~m} \cdot \mathrm{kg}^{-1} \cdot \mathrm{min}^{-1} \cdot{ }^{\mathrm{l}-4}$ Flowmeters on the anaesthesia machine were set to deliver a FGF of $\geq 80 \mathrm{ml} \cdot \mathrm{kg}^{-1} \cdot \mathrm{min}^{-1}$. To insure the accuracy of FGF delivery, the flowmeters on the anaesthesia machine were calibrated each day to a paediattic turbine-vane flowmeter (Boehringer Laboratories, Wynnewood, PA 19096). Peak end-expired isoflurane concentrations and inspired and expired $\mathrm{CO}_{2}$ values were determined at 0.5-1.5 min interuals using mass spectroscopy (The Perkin-Elmer Corp., Pomona, CA 91767). Gas samples were obtained from the endotracheal tube at $6 \mathrm{~cm}$ distal (relative to anaesthesia machine) from the " $Y$ " of the non-coaxial breathing circuit. At these ventilator settings $\mathrm{PECO}_{2}$ was $<34 \mathrm{mmHg}$ in all patients.

\section{Controlled ventilation}

FGF and $\mathrm{PECO}_{2}$ values for controlled ventilation were examined in all patients. Values were determined after patients had been receiving isoflurane for $\geq 25 \mathrm{~min}$ and after the inspired concentration of isoflurane had been adjusted to provide a stable end-expired concentration of isoflurane of 1.0 per cent. All data were collected during a period of moderate surgical stimulation of deeper tissues following incision of the skin and surgical exposure.

\section{FGF PROVIDING NORMAL PECO}

To determine the normocapnic FGF value, ventilatory volume was continued at $135-140 \mathrm{ml} \cdot \mathrm{kg}^{-1} \cdot \mathrm{min}^{-1}$ and FGF was decreased from $\geq 80 \mathrm{ml} \cdot \mathrm{kg}^{-1} \cdot \mathrm{min}^{-1}$, in $0.25 \mathrm{~L}$. $\mathrm{min}^{-1}$ steps (5-6 min at each setting) until $\mathrm{PECO}_{2}$ stabilized at $36 \mathrm{mmHg}$. For the purposes of this study $\mathrm{PECO}_{2}=36 \mathrm{mmHg}$ was considered to be normocapnia. Arterial blood samples were obtained for blood gas analysis in $8 / 33$ patients to confirm normocapnia. FGF at normocapnia was recorded for each patient and the values averaged to determine the mean FGF needed to provide normocapnia during controlled ventilation for this group. The reliability of the system was determined from the variability (standard deviation) of the FGF values providing normocapnia.

\section{SENSITIYITY OF PECU 2 TO ALTERED FGF}

The FGF then was set at +10 and $-10 \mathrm{ml} \cdot \mathrm{kg}^{-1} \cdot \mathrm{min}^{-1}$ from the normocapnic FGF (8-10 min at each setting), and $\mathrm{PECO}_{2}$ values recorded. Mean $\mathrm{PECO}_{2}$ at +10 and $-10 \mathrm{ml} \cdot \mathrm{kg}^{-1} \cdot \mathrm{min}^{-1}$ from normocapnic FGF was used to culculate the magnitude of the change in $\mathrm{PECO}_{2}$ produced by varying the FGF from the recommended value during controlled ventilation.

\section{Spontaneous ventilation}

In 19/33 patients the FGF was continued at the high values used for controlled ventilation, and recovery from the effects of pancuronium was permitted. Once full recovery from pancuronium was complete (as assured by a normal muscle response to percutaneous stimulation of the ulnat nerve), patients were allowed to breathe spontaneously until stable $\mathrm{P}_{\mathrm{ECO}}$ values were observed with no rebreathing of $\mathrm{CO}_{2}$ (minimum inspired $\mathrm{CO}_{2}$ of near zero). As above, all data were collected during a period of moderate surgical stimulation of deeper tissues and a stable endexpired concentration of isoflurane of 1.0 per cent.

\section{FGF THAT JUST INDUCES REBREATHING}

To determine the minimum FGF providing stable $\mathrm{PECO}_{2}$, FGF was lowered, in $0.25 \mathrm{~L} \cdot \mathrm{min}^{-1}$ steps (5-6 min at each setting) until rebreathing occurred (minimum inspired $\mathrm{CO}_{2}>2 \mathrm{mmHg}$ ) without a detectable increase in $\mathrm{PECO}_{2}$. The mean of these FGF values was considered the minimum for providing stable $\mathrm{PECO}_{2}$. The reliability of the system was determined from the variability of FGF values that just induced rebreathing.

SENSITIVITY OF $\mathrm{PECO}_{2}$ TO ALTERED FGF

FGF then was lowered further, in $0.25 \mathrm{~L} \cdot \mathrm{min}^{-1}$ steps 
TABLE Fresh gas fow, end-expired $\mathrm{CO}_{2}$ and ventilatory volume, mean $\pm \mathrm{SD}$

\begin{tabular}{|c|c|c|c|}
\hline & $\begin{array}{l}\text { Fresh gas flow } \\
m l \cdot \mathrm{kg}^{-1} \cdot \mathrm{min}^{-1}\end{array}$ & $\begin{array}{l}\mathrm{PECO}_{2} \\
\mathrm{mmHg}\end{array}$ & $\begin{array}{l}\text { Ventilertary volune } \\
L \cdot \text { min }^{-1}\end{array}$ \\
\hline \multirow[t]{3}{*}{ Controlled ventilation $\mathrm{n}=\mathbf{3 3}$} & $77.4 \pm 10.4$ & $34.8 \pm 0.5^{*}$ & $8.3 \pm 1.6$ \\
\hline & $67.4 \pm 10.3$ & $\begin{array}{l}36 \pm 0.3 \\
\text { (defined as normocapnia) }\end{array}$ & $8.3 \pm 1.6$ \\
\hline & $57.4 \pm 10.2$ & $38.8 \pm 0.9^{*}$ & $8.3 \pm 1.6$ \\
\hline \multirow[t]{3}{*}{ Spontaneous ventilation $n=19$} & $54.9 \pm 7.2$ & $41.6 \pm 3.8$ & $8.8 \pm 1.7$ \\
\hline & $51.6 \pm 7.4$ & $41.6 \pm 3.9$ & $10.2=2.0 \ddagger$ \\
\hline & $48.3 \pm 6.8$ & $45.1 \pm 4.2 \dagger$ & $10.3 \pm 2.07$ \\
\hline
\end{tabular}

*Significantly different from $\mathrm{PECO}_{2}$ at nomocapnic FGF, $\mathrm{p}<0.05$.

$\dagger$ Significantly different from $\mathrm{PECO}_{2}$ at $\mathrm{FGF} \geq 51.6 \mathrm{ml} \cdot \mathrm{kg}^{-1} \cdot \mathrm{min}^{-1}, \mathrm{p}<0.05$.

¥Significantly different from ventilatory volume at $F G F \geq 54.9 \mathrm{ml} \cdot \mathrm{kg}^{-1} \cdot \mathrm{min}^{-1}, \mathrm{p}<0.05$.

(5-6 min at each setting), until $\mathrm{PECO}_{2}$ values rose by more than twice the variability of the values on the mass spectrometer at stable $\mathrm{PECO}_{2}$, i.e., an increase in $\mathrm{PECO}_{2}$ of $\geq 3 \mathrm{mmHg}$ from stable values. The mean of these lower FGF values was considered the FGF at which a significant increase in $\mathrm{PECO}_{2}$ occurred during spontaneous ventilation. Mean $\mathrm{PECO}_{2}$ at this FGF represented the magnitude of the change in $\mathrm{PECO}_{2}$ produced by lowering FGF from the value that just induced rebreathing during spontaneous ventilation. Mean $\mathrm{PECO}_{2}$ at the FGF step just prior to that which just induced rebreathing represented the magnitude of change in $\mathrm{PECO}_{2}$ produced by raising FGF from the minimum value providing stable $\mathrm{PeCO}_{2}$. Respiratory rate and tidal volume were recorded for each step change in FGF during sptontaneous ventilation. Ventilatory volume at each step change in FGF was determined as the product of respiratory rate and tidal volume.

$\mathrm{PeCO} \mathrm{CO}_{2}$ values at altered FGF were compared to $\mathrm{PECO}_{2}$ values at either the $\mathrm{FGF}$ providing normocapnoia (controlled ventilation) or the FGF that just induced rebreathing (spontaneous ventilation) using Student's $t$ test for paired values with the Bonferroni correction. A $p$ value less than 0.05 was considered significant.

\section{Results}

Patient characteristics (mean $\pm \mathrm{SD}$ ) were as follows: agc $=39.9 \pm 15.8$ years, and wcight $=60.0 \pm 9.9 \mathrm{~kg}$. There were 9 males and 24 females.

\section{Controlled ventilation}

The FGF providing normocapnia ( $\left(\mathrm{PECO}_{2}=36 \mathrm{mmI}\right.$ ) for controlled ventilation was $67.4 \pm 10.3 \mathrm{ml} \cdot \mathrm{kg}^{-1} \cdot \mathrm{min}^{-1}$ (mean $\pm \mathrm{SD}$, Table). "Nomocapnic FGF" was lower in females $\left(63.8 \pm 10.5 \mathrm{ml} \cdot \mathrm{kg}^{-1} \cdot \mathrm{min}^{-1}, \mathrm{n}=24\right)$ than in males $\left(76.9 \pm 9.9 \mathrm{ml} \cdot \mathrm{kg}^{-1} \cdot \mathrm{min}^{-1}, \mathrm{n}=9\right)$. Arterial blood samples obtained when $\mathrm{PECO}_{2}=36 \mathrm{mmHg}$ ( $8 / 33$ patients) confirmed normocapnia, with all $\mathrm{PaCO}_{2}$ values equalling $39-40 \mathrm{mmHg}$. At FGF $+10 \mathrm{ml} \cdot \mathrm{kg}^{-1} \cdot \mathrm{min}^{-1}$ above normocapnic FGF, $\mathrm{PECO}_{2}$ was $34.8 \pm 0.5 \mathrm{mmHg}$, a fall in $\mathrm{PECO}_{2}$ of $1.2 \mathrm{mmHg}$ from normocapnia. At FGF $-10 \mathrm{ml} \cdot \mathrm{kg}^{-1} \cdot \mathrm{min}^{-1}$ below normocapnic FGF, $\mathrm{PECO}_{2}$ was $38.8 \pm 0.9 \mathrm{mmHg}$, a rise in $\mathrm{PECO}_{2}$ of $2.8 \mathrm{mmHg}$ from normocapnia. The calculated mean $\mathrm{PeCO}_{2}$ change for alteration of FGF was 0.2 $\mathrm{mmHg} / \mathrm{ml} \cdot \mathrm{kg}^{-1} \cdot \mathrm{min}^{-1}$.

\section{Spontareous ventilation}

During spontaneous ventilation $\mathrm{PECO}_{2}$ was $41.6 \pm$ $3.9 \mathrm{mmHg}$ when FGF was still set at high values. As FGF was lowered, rebreathing of $\mathrm{CO}_{2}$ (minimum inspired $\mathrm{CO}_{2}$ $>2 \mathrm{mmHg}$ ) without a detectable increase in $\mathrm{PECO}_{2}$ occurred when FGF reached $51.6 \pm 7.4 \mathrm{ml} \cdot \mathrm{kg}^{-1} \cdot \mathrm{min}^{-1}$ (Table). "Rebreathing FGF" was lower in females (49.1 $\left.\pm 7.3 \mathrm{ml} \cdot \mathrm{kg}^{-1} \cdot \min ^{-1}, \mathrm{n}=14\right)$ than in males $(59.1 \pm$ $7.4 \mathrm{ml} \cdot \mathrm{kg}^{-1} \cdot \mathrm{min}^{-1}, \mathrm{n}=5$ ). Significant increase in $\mathrm{PECO}$ occurred when the FGF was further reduced to $48.3 \pm$ $6.8 \mathrm{ml} \cdot \mathrm{kg}^{-1} \cdot \mathrm{min}^{-1}$. Thus, the minimum FGF providing stable $\mathrm{PECO}_{2}$ for spontaneous ventilation was $51.6 \pm$ $7.4 \mathrm{ml} \cdot \mathrm{kg}^{-1} \cdot \mathrm{min}^{-1}$. At the lower FGF, $\mathrm{PECO}_{2}$ was $45.1 \pm$ $4.2 \mathrm{mmHg}$. The calculated mean $\mathrm{PECO}_{2}$ change for reduction of $\mathrm{FGF}$ was $1.1 \mathrm{mmHg} / \mathrm{ml} \cdot \mathrm{kg}^{-1} \cdot \mathrm{min}^{-1}$.

Ventilatory volume increased as $\mathrm{FGF}$ was lowered to the value where minimum inspired $\mathrm{CO}_{2}$ exceeded $2 \mathrm{mmHg}$. However, ventilatory volume rose no higher as FGF was lowcred below the value that just induced rebreathing and $\mathrm{PECO}_{2}$ increased. That ventilatory volume did not increase when FGF was reduced to this low value identifies a potential hazard should any further reduction of $\mathrm{FGF}$ or increase of $\mathrm{CO}_{2}$ production occur.

\section{Discussion}

When the Humphrey A.D.E.System is used, elimination of $\mathrm{CO}_{2}$ from the lung is determined by two factors, namely ventilatory volume and FGF. During controlled ventilation there is a reciprocal relationship betwecn these 
two determinants so that as ventilatory volume is reduced FGF must be increased to maintain $\mathrm{PECO}_{2}$ constant and vice versa. During controlled ventilation ventilatory volume is set to a fixed high value. As FGF is lowered from high values, $\mathrm{PACO}_{2}$ increases until normocapnia is achieved. In our study we observed that a FGF of $67.4 \pm$ $10.3 \mathrm{ml} \cdot \mathrm{kg}^{-1} \cdot \mathrm{min}^{-1}$ provided normocapnia. Our results confirm the FGF value recommended by Humphrey for controlled ventilation $\left(70 \mathrm{ml} \cdot \mathrm{kg}^{-1} \cdot \mathrm{min}^{-1}\right)$. $^{2,3}$ Our results also are in good agreement with a recent preliminary publication by Shulman and Brodsky who examined five patients during controlled ventilation and reported that normocapnia was achieved with a FGF of $70 \mathrm{ml} \cdot \mathrm{kg}^{-1}$. $\min ^{-1} .5$ In both our study and the previous ones the ventilatory volume was set at $135-140 \mathrm{ml} \cdot \mathrm{kg}^{-1} \cdot \mathrm{min}^{-1}$. That the mean FGF required for females was lower than for males is consistent with a previous report by Romano et al. ${ }^{7}$

Our results indicate that the variability of the FGF required to produce normocapnia for controlled ventilation is large ( $S D=15$ per cent of mean FGF). Only part of this variability can be accounted for by the magnitude of the step changes in FGF used here $\left(0.25 \mathrm{~L} \cdot \mathrm{min}^{-1}\right)$. The step changes in FGF used here are similar to those used in previous studies $\left.\left(0.1-0.51 \cdot \mathrm{min}^{-1}\right)\right)^{2.3 .6}$

However, the low reliability of the recommended FGF setting for controlled ventilation is offset by the low sensitivity of the system when FGF is not set exactly at the normocapnoic FGF. Varying the FGF by $\pm 10 \mathrm{ml} \cdot \mathrm{kg}^{-1}$. $\mathrm{min}^{-1}$ from the mean FGF that provided normocapnoia resulted in clinically insignificant changes in $\mathrm{PECO}_{2}$ $(1-3 \mathrm{mmHg})$. That low reliability was offset by low sensitivity is consistent with comments made about use of the Bain system for controlled ventilation, ${ }^{8}$

During spontaneous ventilation with the Humphrey A.D.E. system $\mathrm{CO}_{2}$ elimination from the lung still is determined by ventilatory volume and FGF. However, ventilatory volume is not set at a fixed value but instead is determined by the patients' own respiratory rate and tidal volume. Respiratory rate and tidal volume also vary with surgical stimulation and depth of anaesthesia. ${ }^{9}$ In attempt to control these variables, data were collected only after a stable end-expired concentration of isoflurane had been achieved and when a moderate level of surgical stimulation was present. We observed that as FGF was lowered from high values patients initially maintained a stable $\mathrm{PeCO}_{2}$ by increasing their ventilatory volume. As FGF was lowered further patients were unable to proportion. ately increase their ventilatory volume and rebreathing of $\mathrm{CO}_{2}$ (defined as minimum inspired $\mathrm{CO}_{2}>2 \mathrm{mmHg}$ ) occurred at a FGF of $51.6 \pm 7.4 \mathrm{ml} \cdot \mathrm{kg}^{-1} \cdot \mathrm{min}^{-1}$. This value is consistent with previous reports of the FGF at which rebreathing occurs during spontaneous ventilation with the Humphrey A.D.E. system during anaesthesia with halothane $e^{1,3.6}$ or isoflurane ${ }^{5}$ (range of $45.6 \pm 14.9$ to $56 \mathrm{ml} \cdot \mathrm{kg}^{-1} \cdot \mathrm{min}^{-1}$ ). Based on the "rebreathing FGF" of about $52 \mathrm{ml} \cdot \mathrm{kg}^{-1} \cdot \mathrm{min}^{-1}$ determined in this study, the calculated FGFs to just induce rebreathing in 84 per cent (I SD) and 97.5 per cent (2 SD) of patients are 59 and $66 \mathrm{ml} \cdot \mathrm{kg}^{-1} \cdot \mathrm{min}^{-1}$, respectively. That the mean FGF required for females was lower than for males is consistent with a previous report by Romano et al. ${ }^{\text {? }}$

For the determination of "rebreathing FGF" in the present study, minimum inspired $\mathrm{CO}_{2}$ was recorded during the inspiratory phase and rebreathing was defined as minimum inspired $\mathrm{CO}_{2}>2 \mathrm{mmHg}$. It is possible that as FGF was lowered from high values, $\mathrm{CO}_{2}$ was present in inspired gases at times other than when minimum inspired $\mathrm{CO}_{2}$ occurred. $\mathrm{CO}_{2}$ in inspired gases may stimulate ventilatory volume causing little change in $\mathrm{PECO}_{2}$ so long as patients are able to increase ventilatory volume. Had rebreathing been defined relative to mean inspired $\mathrm{CO}_{2}$, the FGF at which rebreathing occurred would have been higher than that reported here.

In the present study $\mathrm{PECO}_{2}$ at the FGF that just induced rebreathing was $41.6 \pm 3.9 \mathrm{mmHg}$. A previous preliminary study reported higher $\mathrm{P} E \mathrm{CO}_{2}(49.6 \pm 3.7 \mathrm{mmHg})$ at the FGF that just induced rebreathing. ${ }^{5}$ However, in that preliminary study patients received meperidine $1 \mathrm{mg} \cdot \mathrm{kg}^{-1}$ IM preoperatively. Thus, narcotic-induced respiratory depression may have contributed to the higher $\mathrm{PECO}_{2}$ reported in that preliminary study.

Our results indicate that the variability of the FGF that just induced rebreathing for spontaneous ventilation is large (SD $=14$ per cent of mean FGF), indicating low reliability of the recommended FGF setting for controlled ventilation. This large variability in the FGF requirement is consistent with previous reports ( $S D=10-33$ per cent of mean FGF). ${ }^{1,6}$ Further, the sensitivity of the system is high at FGFs ten per cent below the mean, although at FGFs ten per cent above the mean sensitivity falls to zero, i.e., $\mathrm{P} 6 \mathrm{CO}_{2}$ cannot be further reduced by increasing the FGF. That the sensitivity of the Humphrey A.D.E. system during spontaneous ventilation was high during low FGF but fell to zero at high FGF is consistent with a recent report by Jonsson on the sensitivity of the Lack system. ${ }^{10}$ The Lack system functions identically to the Humphrey A.D.E. system set in its " $A$ " mode for spontaneous ventilation. ${ }^{3}$ Jonsson reported high sensitivity at low FGF and sensitivity of zero at FGF $>5$ $\mathrm{L} \cdot \mathrm{min}^{-1}$ with the Lack system. In contrast, in the same study high sensitivity at low FGF and moderate sensitivity at high FGF was reported with the Bain system. ${ }^{10}$

When FGF was lowered by $0.25 \mathrm{~L} \cdot \mathrm{min}^{-1}$ from the value that just induced rebreathing, patients did not increase their ventilatory volume and a detectable in- 
crease in $\mathrm{PECO}_{2}$ occurred. Lowering FGF by only $3 \mathrm{ml} \cdot \mathrm{kg}^{-1} \cdot \mathrm{min}^{-1}$ increased $\mathrm{PECO}_{2}$ by $4 \mathrm{mmHg}$. That patients appeared to have reached maximum ventilatory volume for their level of anaesthesia suggests that further reduction of FGF would cause even greater, proportionate increases of $\mathrm{PECO}_{2}$.

As regards clinical practice, our results suggest that, for controlled ventilation, using the recommended FGF $\left(70 \mathrm{ml} \cdot \mathrm{kg}^{-1} \cdot \mathrm{min}^{-1}\right)$ with a ventilatory volume of $140 \mathrm{ml}$. $\mathrm{kg}^{-1} \cdot \mathrm{min}^{-1}$ should prove satisfactory for usual adult patients (though perhaps not for patients with fever, sepsis or increased dead space to tidal volume ratios). It should not be necessary to monitor $\mathrm{PECO}_{2}$ because of FGF of $70 \mathrm{ml} \cdot \mathrm{kg}^{-1} \cdot \mathrm{min}^{-1}$ provides normocapnia $\left(\mathrm{PeCO}_{2}\right.$ of 36 $\pm 0.3 \mathrm{mmHg}$ ) for $>95$ per cent of patients. Though the variability of the FGF providing normocapnia for controlled ventilation was large (SD $\left.= \pm 10 \mathrm{ml} \cdot \mathrm{kg}^{-1} \cdot \mathrm{min}^{-1}\right)$, varying the $\mathrm{FGF}$ by $\pm 10 \mathrm{ml} \cdot \mathrm{kg}^{-1} \cdot \mathrm{min}^{-1}$ resulted in clinically insignificant changes in $\mathrm{PECO}_{2}(1-3 \mathrm{mmHg})$. However, for spontaneous ventilation $\mathrm{PECO}_{2}$ was sensitive to reduction of FGF values below $51 \mathrm{ml} \cdot \mathrm{kg}^{-1} \cdot \mathrm{min}^{-1}$. Lowering FGF by only $3 \mathrm{ml} \cdot \mathrm{kg}^{-1} \cdot \mathrm{min}^{-1}$ increased $\mathrm{PECO}$ by $4 \mathrm{mmHg}$. Because patients appeared to reach maximum ventilatory volume by the time FGF was lowered to just induce rebreathing, any further reduction of FGF or increase of $\mathrm{CO}_{2}$ production should proportionately increase $\mathrm{P} \in \mathrm{CO}_{2}$. Therefore for spontaneous ventilation a higher FGF of $66 \mathrm{ml} \cdot \mathrm{kg}^{-1} \cdot \mathrm{min}^{-1}$ should be used, or some measurement of adequacy of ventilation should be used, such as blood gas sampling, or monitoring $\mathrm{PECO}_{2}$ or transcutaneous $\mathrm{CO}_{2}$.

\section{References}

1 Humphrey D. Brock-Uine JG, Downing JW. Single lever Humphrey A.D.E. low flow universal anaesthetic breathing system. Part I: Comparison with dual lever A.D.E., Magill and Bain systems in anaesthetized spontancously breathing adults. Can Anacsth Soc J 1986; 33: 698-709.

2 Humphrey D, Brock-Utne JG, Downing JW. Single lever Humphrey A.D.A. low flow universal anaesthetic breathing system. Part II: Comparison with Bain system in anaesthetized adults during controlled ventilation. Can Anaesth Soc J 1986; 33: 710-8.

3 Humphrey $D$. A new anaesthetic breathing system combining Mapleson A, D and E principles; a simple apparatus for low flow universal use without carbon dioxide absorption. Anaesthesin 1983; 38: 361-72.

4 Humphrey $D$. The A.D.E. anaesthetic breathing system. Anacsthesia 1984; 39: 715-7.

5 Shulman MS, Brodsky JB. The A.D.E. System-a new anesthetic breathing system (abstract). Anesth Analg 1984; $63: 273$
6 Dixon J, Chakrabarti MK, Morgan $M$, An assessment of the Humphrey A.D.E. System in the Mapleson A mode during spontaneous ventilation. Anaesthesia 1984; 39: 593-6.

7 Romano E, Pegortura M, Fasiola S, Gullo A. Bain anesthetic system and gender. Anaesthesia 1986; 41: 1263-4.

8 Henville JD, Adams $A P$. The Bain anaesthetic system. An assessment during controlled ventilation. Anaesthesia 1976; 31: 247-56.

9 Eger EI, $I$, Dolan $W M$, Stevens $W C_{r}$ Miller RD, Way $W L$. Surgical stimulation antagonizes the respiratory depression produced by forane. Anesthesiology 1972; 36: 544-9.

10 Jonsson $L$. Spontaneous breathing in coaxial Mapleson A and $D$ circuits. A study of factors affecting rebreathing. Acta Universitatus Upsaliensis 1986; 3: 8-9.

\section{Résumé}

Un nowveau circuit respiratoire (le Humphrey A.D.E., modèle à double levier) a été évaluê chez l'adulte afin de déterminer li le débit de gaz frais (DGF) nécessaire pour atteindre un normocapnie durant la ventilation controlée et afin d' induire, do peine, la réinspiration durant une ventilation sponsanée, 2) de $\mathrm{CO}_{2}$ de fin d'expiration $\left(\mathrm{PECO}_{2}\right)$ d̀ ces valeurs du DGF, 3) lo deviation normale des exigences en $D G F$ pour une respiration contrôlée et spontanée (la fiabiliré des réglages recommandés du DGF) et 4) l'importance du changement dans la $\mathrm{PECO}_{2}$ produite par la variation des valeurs de DGF recommandées (sensibilité du système). Les DGF produisant une normocapnie avec une ventilation contrôlée et une réinspiration à peine induite avec une ventilation spontanée étaiem de $67 \pm 10$ et $52 \pm$ $7 \mathrm{ml} \cdot \mathrm{kg}^{-1} \cdot \mathrm{min}^{-1}$ (moyenne $\pm S D$ ) respectivement. Les valeurs de la $\mathrm{PECO}$ étaient de $36.0 \pm 0.3$ et $41.6 \pm 3.9 \mathrm{mmHg}$, respectivement. Duran la ventilation contrôlée la faible fiabilité êtait contrebalancée par la faible sensibilité de relle sorte qu'il se produisait peu de changement dans la PECOP, lorsque le DGF était plus élevé ou plus bas que les valeurs reconnandées $\left(0.2 \mathrm{mmH} \mathrm{g} / \mathrm{ml} \cdot \mathrm{kg}^{-1} \cdot \mathrm{min}^{-1}\right)$. Par contre, durant la ventilation spontanée la faible fiabilité s'ajourait à la sensibilité élevée quand on utilisait des DGF allant au-dessous de la valeur moyenne qui induisait à peine la réinspiration. Un seuil était atteint quand le DGF se trouvant au-dessous des valeurs recommandés causaien des changements importams dons le $\mathrm{PECO}_{2}\left(1.1 \mathrm{mmH} / \mathrm{ml} \cdot \mathrm{kg}^{-1} \cdot \mathrm{min}^{-1}\right)$. En conclusion, le DGF recommandé par Humphrey pour la ventilation contrôtée est satisfaisant. Cependant, le DGF recommandé par Humphrey pour la ventilation spontanée peut aboutir en hypercapnie chez certains patients. Ce résultat peut être prévenu en utilisant un DGF plus élevé à $66 \mathrm{ml} \cdot \mathrm{kg}^{-1} \cdot \mathrm{ntin}^{-1}$ de façon habintulle chez ious les patients ou en utilisant des débits plus faibles avec monitorage du $\mathrm{CO}_{2}$. 